\title{
Effects of stocking densities on growth and survival of Thai Sharpunti (Barbonymus gonionotus) in earthen ponds
}

\author{
M. F. A. Mollah ${ }^{1}$, M. Moniruzzaman ${ }^{2}$ and M. M. Rahman ${ }^{3}$ \\ ${ }^{1}$ Department of Fisheries Biology \& Genetics, Bangladesh Agricultural University, Mymensingh-2202, ${ }^{2}$ Bangladesh \\ Fisheries Research Institute, Riverine Sub-Station, Rangamati Sadar, Rangamati-4500 and ${ }^{3}$ Faculty of Fisheries \\ Science, Hokkaido University, Japan, E-mail: mzaman_bfri@yahoo.com
}

\begin{abstract}
The present study was conducted over 4 months during $1^{\text {st }}$ September to $30^{\text {th }}$ December 2005 to observe the effects of stocking density on growth and survival of Thai Sharpunti, Barbodes gonionotus in 3 earthen ponds of size of 2.8 decimal each. The stocking densities of 80,100 and $120 \mathrm{fish} /$ decimal were treated as $T_{1}, T_{2}$ and $T_{3}$, respectively. All the treatments were subjected to the same feeding regime and fertilization. The range of water quality parameters such as temperature were $30.31,30.16$ and $29.65^{\circ} \mathrm{C}$, transparency were $29.94,37.63$, and $40.02 \mathrm{~cm}$, water depth were 143.91, 148.67 and $151.54 \mathrm{~cm}$, dissolved oxygen were 4.72, 4.35 and $4.24 \mathrm{mg} / \mathrm{l}, \mathrm{pH}$ were $7.71,7.49$ and 7.31 , plankton biomass were $43.05 \times 10^{5} /, 37.97 \times 10^{5} / /$ and $36.05 \times 10^{5} / /$ in $T_{1}, T_{2}$ and $T_{3}$, respectively. Among the growth parameters, mean weight gain were $48.87 \mathrm{~g}, 41.43 \mathrm{~g}$ and $34.09 \mathrm{~g}$, percent weight gain were $698.21 \%$, $591.93 \%$ and $487 \%$, the average daily gains were $1.65,1.54$ and $1.20 \mathrm{~g}$, the specific growth rate were $1.73,1.61$ and $1.47 \%$, in $T_{1}, T_{2}$ and $T_{3}$ respectively. The gross total productions of Barbonymus gonionotus were 1041.96, 1085.71 and $1019.64 \mathrm{~kg} / \mathrm{ha} / 120$ days while the net productions were $911.60,929.46$ and $846.43 \mathrm{~kg} / \mathrm{ha} / 120$ days in $\mathrm{T}_{1}, \mathrm{~T}_{2}$ and $T_{3}$, respectively. The gross and net total productions in $T_{2}$ were highest among the treatments. The highest growth and survival rate were obtained in $\mathrm{T}_{1}$.
\end{abstract}

Keywords: Stocking density, Growth, Survival, Thai Sharpunti

\section{Introduction}

Thai Sharpunti, B. gonionotus (Bleeker, 1850) is a fresh water food fish of Thailand where it is locally known as Pla Ta Pian Khao or Thai silver barb. It was introduced into Bangladesh in 1977 from Thailand because of its high yielding potential and has become increasingly popular for its high growth, good taste and bright silvery appearance. It is also a suitable species for culturing in the seasonal ponds and rice fields in monoculture. This species has high production potential compared to native carps (Kohinoor et al., 1994a). It grows fast at high stocking densities (Karim et al. 1988). It can survive in brackish water at a salinity more than $7.0 \mathrm{ppt}$ and grows to table size within three to four months (Gupta and Rab, 1994). It normally spawns in flood and running waters. This species can grow well even in shallow, turbid ponds and high production can be obtained at a low cost (Gupta, 1991). It is an important exotic species in Bangladesh.

Stocking density is an important parameter in fish culture operations, since it has direct effects on growth and survival and hence on production (Backiel and Le Cren, 1978). It is an established fact that growth rate progressively increases as the stocking density decreases and vice-versa. This is because a relatively less number of fish of similar size in a pond could get more space, food and dissolved oxygen etc. However there may be no relationship between food abundance and growth rate when a space limiting effect operates on the population (Johnson, 1965). Higher stocking density may cause crowding effects and reduction of growth rate. Overcrowding may easily induce "size hierarchies" within the fish population as a result smaller fish is inhibited from feeding satisfactorily because of the presence of the larger ones. In many fish culture practices where the fish are confined in a restricted space, this size dominance in feeding is often of considerable significance (Brett, 1974; Weatherly, 1976).

Stocking densities and management measures practiced by pond operators in Bangladesh are not based on scientific knowledge, thus resulting in poor growth and survival of fry. To obtain maximum economic returns it would be necessary to stock the ponds at right stocking densities for optimum growth. 
Growth and survival of fry and fingerlings in earthen ponds depend on the density of stocking, type and quality of fertilizer applied and supplementary feed provided. To obtain maximum economic return it would be necessary to stock the ponds at optimum stocking densities for desired growth and survival of fry. However, there is very little available report on the effects of stocking density on the growth and production of Barbonymus gonionotus in our country. Therefore, the present study was undertaken to determine a suitable stocking density to obtain maximum growth and profit in a monoculture system of out door earthen ponds.

\section{Materials and Methods}

\section{Study area}

The experiment was conducted for a period of four months from $1^{\text {st }}$ September to $30^{\text {th }}$ December 2005 in the three small research ponds of the Department of Fisheries Biology and Genetics adjacent to the Faculty of Fisheries, Bangladesh Agricultural University.

\section{Pond preparation}

The ponds were dried by draining out the water by pump. Lime was liquefied and applied at a rate of $1 \mathrm{~kg}$ per decimal by spreading homogeneously on the pond bottom. After one week ponds were filled with water and urea and TSP were applied at the rate of $200 \mathrm{~g}$ and $100 \mathrm{~g}$ per decimal respectively.

\section{Experimental design}

Each pond of 2.8 decimal was divided into two by fencing right at the middle by the help of synthetic durable nets and bamboos. Therefore, the six segments of 3 ponds were ultimately used to conduct the experiment in completely randomized design for testing 3 stocking densities viz, 80, 100 and 120 fish/decimal with two replications in each treatment.

The ponds were similar in shape, depth, basin configuration and pattern including water supply facilities. The water depth was maintained to a maximum of $1.5 \mathrm{~m}$. There was inflow and outflow mechanism to maintain the water level coming from a deep tube well.

\section{Stocking of Thai Sharpunti}

The ponds were stocked with fingerlings after 7 days of fertilization. Before stocking all fingerlings were kept into a hapa for half an hour for acclimatization and the initial length and weight of fish were recorded individually in ' $\mathrm{cm}$ ' and ' $\mathrm{g}$ ' respectively with the help of a measuring scale and a digital electric balance (OHAUS, Model CT 1200-S, USA). All ponds were stocked with B. gonionotus of $7 \pm 0.01 \mathrm{~g}$ weight and $8.20 \pm 0.5 \mathrm{~cm}$ length. The length and weight of 20 randomly selected fish were recorded for each pond. Before taking the weight, the excess water of the body of the fish was soaked by soft tissue paper.

\section{Post stocking management}

To determine growth and production of fish following management steps were taken:

\section{i) Feeding and fertilization}

Fingerlings were fed at the rate of $15 \%$ of body weight in the first month. The feeding rate was reduced to $10 \%$ of the body weight in the 2 nd month and $5 \%$ of the body weight for the rest two months. The quantity of feed required was determined fortnightly through sampling of fish. The total amount of feed was divided into two equal rations for using at $800 \mathrm{hrs}$ and $1800 \mathrm{hrs}$. The feed was dispersed by hand over the water. A record of supplied feed was maintained to determine the food conversion ratio (FCR). The ponds were also fertilized with cowdung at the rate of $1500 \mathrm{~kg} / \mathrm{ha}$ at fortnightly interval. 
ii) Sampling of the experimental fish

Fortnightly sampling was done using a seine net to observe the growth of fish and to adjust the feeding rate. Weight of fish in each sampling was measured to the nearest gram while the length of each fish was measured to the nearest centimeter. General pond condition and fish health conditions were monitored regularly during the culture period. The sampled fish were handled carefully. Any mortality of fish during the study period observed was recorded.

\section{Collection and treatment of water samples}

Water samples were collected from each pond using a Kammerer type water sampler. On each sampling day clean white plastic bottles with caps having a volume of 1 litre each and marked with pond number were used to contain the collected water samples.

\section{Water quality parameters}

The water quality parameters such as water depth, transparency, temperature, dissolved oxygen (DO) and $\mathrm{pH}$ were monitored fortnightly throughout the experimental period. Water temperature of the ponds was measured with the help of Celsius thermometer. Dissolved oxygen of the pond water was measured by using an oxygen meter (Oxymeter WTW, Multi 340i). A pH meter (Jenway, model 3020, UK) was used to measure the $\mathrm{pH}$ of water. Water transparency and depth were measured by using secchi disc and weighted measuring tape respectively. All analyses were done in the Water Quality and Pond Dynamics Laboratory of the Faculty of Fisheries.

\section{Plankton biomass}

Collection, preservation and enumeration of plankton: Plankton samples were collected fortnightly from experimental ponds. Ten litre samples of pond water were collected from different areas and depth of the pond and filtered through a fine mesh $(25 \mathrm{~mm})$ phytoplankton net. Filtered sample was taken into a measuring cylinder and carefully made up to standard volume with distilled water. Using a plastic tubing, water was siphoned off from the measuring cylinder and plankton were concentrated into $50 \mathrm{ml}$ and preserved using $5 \%$ buffered formalin in small plastic vials for subsequent studies. From each $10 \mathrm{ml}$ preserved sample, $1 \mathrm{ml}$ subsample was examined using Sedgwick-Rafter cell (S-R cell) and binocular microscope (Olympus BH2).

Counting: The S-R counting cell is a special type of slide having a counting chamber which is $50 \mathrm{~mm}$ long, $20 \mathrm{~mm}$ wide and $1 \mathrm{~mm}$ deep; the volume of the chamber is $1 \mathrm{ml}$. The counting chamber is equally divided into 100 fields, each having a volume of $0.001 \mathrm{ml}$.

Calculation: Calculation of plankton samples were done by using the following formula (Rahman, 1992).

$$
N=\frac{A \times 100 \times C}{V \times F \times L}
$$

Where,

$$
\begin{aligned}
& N=\text { No. of plankton cells or units per litre or original water } \\
& A=\text { Total no. of plankton counted } \\
& C=\text { Volume of final concentrate of the sample in } \mathrm{ml} . \\
& V=\text { Volume of a field }=1 \mathrm{~mm}^{3} \\
& F=\text { No. of fields counted } \\
& L=\text { Volume of original water in litre }
\end{aligned}
$$

Harvesting of Thai Sharpunti: After 4 months of rearing, the fish were harvested by repeated netting using a seine net. During harvesting all fish were counted and weighed individually for each pond to assess the survival rate and production. 
Analytical methods: The proximate composition of feed ingredients and experimental diet was analyzed in triplicate according to standard procedures given by Association of Official Analytical Chemists (AOAC, 1980).

Analysis of the experimental data: Experimental data collected during the growth trial in different treatments were evaluated by using the following parameters.

\section{Growth parameters}

a) Weight gain $(\mathbf{g})=$ mean final fish weight $(\mathrm{g})$ - mean initial fish weight $(\mathrm{g})$

b) Percent weight gain $=\frac{\text { Mean final fish weight }- \text { Mean initial fish weight }}{\text { Mean initial fish weight }} \times 100$

c) Specific growth rate (SGR \% per day)

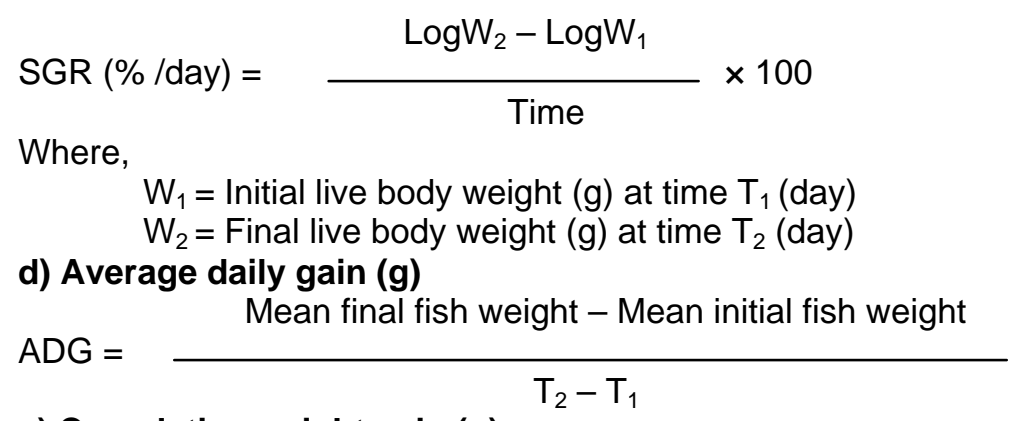

e) Cumulative weight gain (g)

CWG $=$ Mean final fish weight

\section{Statistical analysis}

Duncan's new multiple range test (DMRT) and one-way analysis of variance (ANOVA) were used to determine the effect of different stocking densities on the growth of fish to identify the $1 \%$ level of significance of variance among the treatment means. Standard deviations $( \pm S D)$ of treatment means were also calculated.

\section{Results and Discussion}

\section{Water quality parameters}

A number of physico-chemical parameters of pond water were determined which produced a large number of data. Comparison of mean values of water quality parameters among three treatments are presented in Table 1. Graphical representation of the major variable parameters are shown in Fig.1 a to $\mathrm{f}$. One- way analysis of Variance (ANOVA) was performed to observe the significant difference among the treatments which are also shown in Table 1.

\section{Water temperature}

Water temperature of the ponds under different treatments were recorded fortnightly. The water temperature was more or less similar in different ponds. The mean values of water temperature were $30.31 \pm 0.98,30.16 \pm 0.77$ and $29.65 \pm 0.57{ }^{\circ} \mathrm{C}$ in $\mathrm{T}_{1}, \mathrm{~T}_{2}$ and $\mathrm{T}_{3}$ respectively (Table 1). The ranges of water temperature were 26.30 to $34.35{ }^{\circ} \mathrm{C}$ in $\mathrm{T}_{1}, 25.20$ to $33.30{ }^{\circ} \mathrm{C}$ in $\mathrm{T}_{2}$ and 25.35 to $33.35{ }^{\circ} \mathrm{C}$ in $\mathrm{T}_{3}$. The highest value was observed to be $34.35^{\circ} \mathrm{C}$ in $\mathrm{T}_{1}$ in September and the lowest was observed to be 25.20 ${ }^{0} \mathrm{C}$ in $\mathrm{T}_{2}$ in December. There was no significant difference $(\mathrm{P}>0.01)$ among the treatments when ANOVA was performed (Table 1). The mean values of water temperature were more or less similar in all the treatments. 
Transparency: Water transparency was observed to vary from one pond to another and also from one month to another. The mean values of water transparency were $29.94 \pm 0.81,37.63 \pm 0.53$ and $40.02 \pm$ $0.57 \mathrm{~cm}$ in $T_{1}, T_{2}$ and $T_{3}$ respectively (Table 1). The ranges of water transparency were 19.89 to $40.03 \mathrm{~cm}$ in $_{1}, 27.31$ to $46.52 \mathrm{~cm}$ in $\mathrm{T}_{2}$ and 28.91 to $46.90 \mathrm{~cm}$ in $\mathrm{T}_{3}$. The highest transparency value was recorded as $46.90 \mathrm{~cm}$ in treatment 3 and the lowest value was $19.89 \mathrm{~cm}$ in treatment 1.

Depth of water: Water depth was more or less same in different treatments during the study period and they were not significantly different. The mean values of water depth $(\mathrm{cm})$ were $143.91 \pm 0.12,148.67 \pm$ 3.43 and $151.54 \pm 1.69 \mathrm{~cm}$ in treatment 1 , treatment 2 and treatment 3 respectively (Table 1 ).

Dissolved oxygen $(\mathbf{m g} / \mathrm{L})$ : Dissolved oxygen is one of the most important factors which was recorded during the experimental period. During the period of study, the values of dissolved oxygen ranged from 3.84 to $5.30 \mathrm{mg} / \mathrm{l}, 3.91$ to $4.78 \mathrm{mg} / \mathrm{l}$ and 3.46 to $5.09 \mathrm{mg} / \mathrm{l}$ and mean values were $4.72 \pm 0.22,4.35 \pm 0.88$ and $4.24 \pm 0.44 \mathrm{mg} / \mathrm{l}$ in treatments 1,2 and 3 respectively (Table 1 ). The mean value of dissolved oxygen were more or less similar in all treatments and there was significant difference among them.

Hydrogen- Ion- concentration $(\mathrm{pH})$ : Throughout the study period, the $\mathrm{pH}$ values of the pond water under the three treatments were found to be slightly alkaline. The values of $\mathrm{pH}$ ranged from 7.13 to 8.44 , 6.88 to 8.21 and 6.80 to 8.10 and mean values were $7.71 \pm 0.29,7.49 \pm 0.10$ and $7.31 \pm 0.41$ in $T_{1}, T_{2}$ and $T_{3}$ respectively (Table 1$)$. One-way ANOVA showed no significant $(P>0.01)$ difference among the three treatments (Table 1).

Plankton biomass: During the experimental period the plankton population varied from $41.25 \times 10^{5}$ to $44.25 \times 10^{5} / /$ with mean value of $(43.05 \pm 3.64) / /$ in treatment 1 . Plankton population was $36.95 \times 10^{5}$ to $39.50 \times 10^{5} / /$ with mean value of $(37.97 \pm 2.66) / /$ in treatment 2 and $34.65 \times 10^{5}$ to $36.45 \times 10^{5} / /$ with mean value of $(36.05 \pm 2.25) / /$ in treatment 3 . The highest abundance of plankton population was observed in treatment 1 (Table 1.)

Table 1. Comparison of water quality parameters (mean \pm SD) among three treatments

\begin{tabular}{|l|c|c|c|c|}
\hline \multicolumn{1}{|c|}{ Parameters } & Treatment- 1 & Treatment- 2 & Treatment- 3 & F-value \\
\hline${\text { Temperature }\left({ }^{0} \mathrm{C}\right)}$ & $30.31 \pm 0.98^{\mathrm{a}}$ & $30.16 \pm 0.77^{\mathrm{a}}$ & $29.65 \pm 0.57^{\mathrm{a}}$ & $0.457 \mathrm{NS}$ \\
\hline Transparency $(\mathrm{cm})$ & $29.94 \pm 0.81^{\mathrm{a}}$ & $37.63 \pm 0.53^{\mathrm{a}}$ & $40.02 \pm 0.57^{\mathrm{a}}$ & $0.583 \mathrm{NS}$ \\
\hline Depth $(\mathrm{cm})$ & $143.91 \pm 0.12^{\mathrm{a}}$ & $148.67 \pm 3.43^{\mathrm{a}}$ & $151.54 \pm 1.69^{\mathrm{a}}$ & $0.073 \mathrm{NS}$ \\
\hline $\mathrm{DO}(\mathrm{mg} / \mathrm{L})$ & $4.72 \pm 0.22^{\mathrm{a}}$ & $4.35 \pm 0.88^{\mathrm{a}}$ & $4.24 \pm 0.44^{\mathrm{a}}$ & $0.796 \mathrm{NS}$ \\
\hline $\mathrm{pH}$ & $7.71 \pm 0.29^{\mathrm{a}}$ & $7.49 \pm 0.10^{\mathrm{a}}$ & $7.31 \pm 0.41^{\mathrm{a}}$ & $0.144 \mathrm{NS}$ \\
\hline Plankton biomass & $43.05 \pm 3.64^{\mathrm{a}}$ & $37.97 \pm 2.66^{\mathrm{a}}$ & $36.05 \pm 2.25^{\mathrm{a}}$ & $53.25 * *$ \\
\hline
\end{tabular}

Plankton biomass $=$ no. $\times 10^{5} \mathrm{cell} / \mathrm{l}$

NS indicates non significant at $1 \%$ level.

Figures in the same row with sane letters are not significantly different $(P>0.01)$

Growth parameters: Fortnightly growth parameters of Barbonymus gonionotus under three stocking densities using the same feeding regime were studied during the experimental period. The growth parameters like initial weight (g), cumulative weight gain (g), weight gain (g), percentage weight gain (\%), specific growth rate or SGR (\% per day) were recorded and shown in Table 2.

Weight gain (g): The body weight increased during the experimental period. The significantly $(\mathrm{P}<0.01)$ highest growth (48.87 \pm 1.17$)$ was observed in $T_{1}$ followed by $T_{2}(41.43 \pm 1.80)$ and the lowest growth (34.09 \pm 1.47 ) was observed in $T_{3}$.

Percentage weight gain (\%): The percent weight gain (\%) of Barbonymus gonionotus in different treatments ranged from $(487 \pm 21.01)$ to $(698.21 \pm 16.67)$. The lowest percent weight gain of $487 \pm 21.01$ was observed in $T_{3}$ while the significantly $(P<0.01)$ highest percent weight gain $698.21 \pm 16.67$ was observed in $\mathrm{T}_{1}$ followed by $\mathrm{T}_{2}(591.93 \pm 25.76)$. 


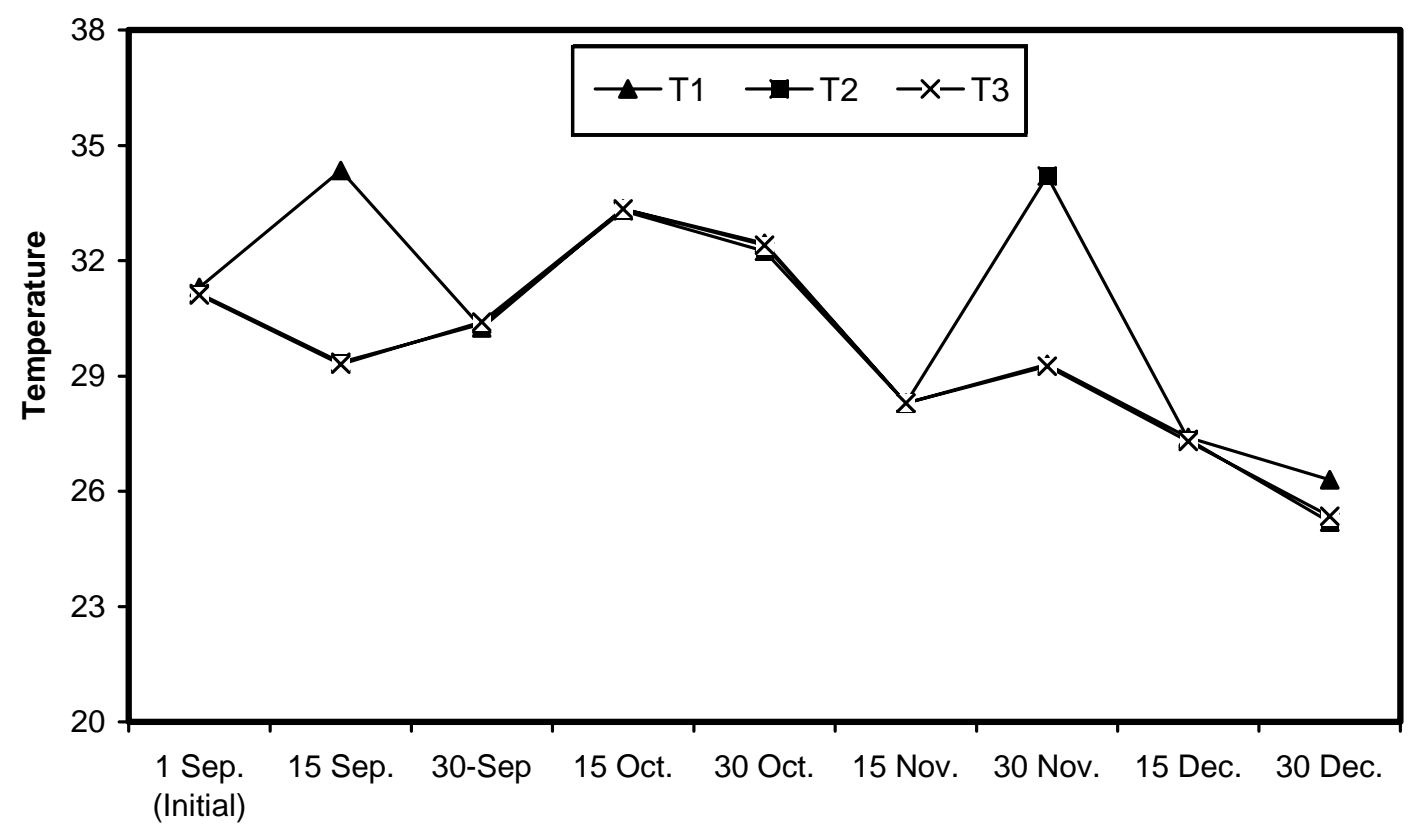

Sampling date

Fig. 1. a Showing the variations of temperature $\left({ }^{0} \mathrm{C}\right)$ under three treatments

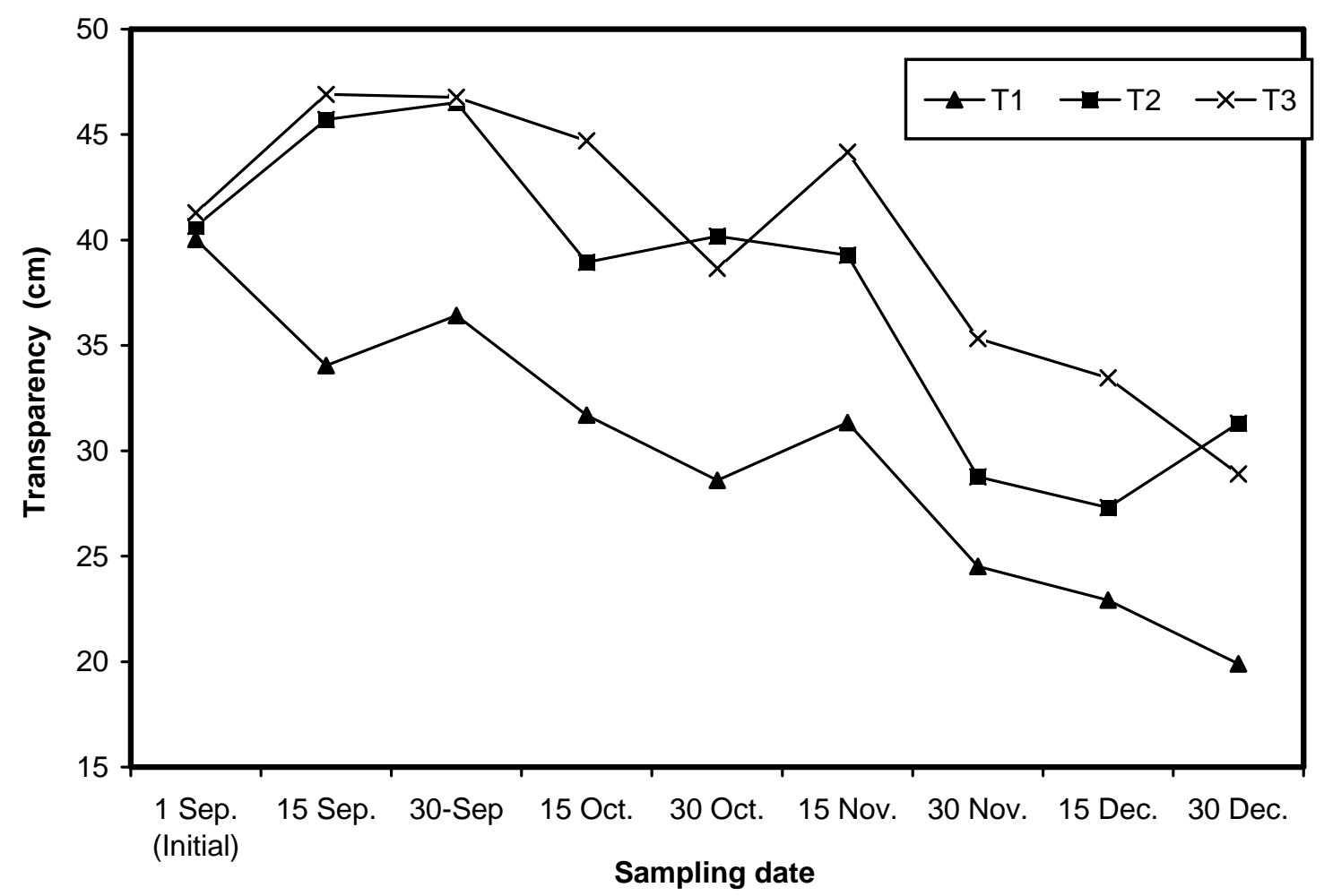

Fig. 1. b Showing the variations of transparency $(\mathrm{cm})$ under three treatments 


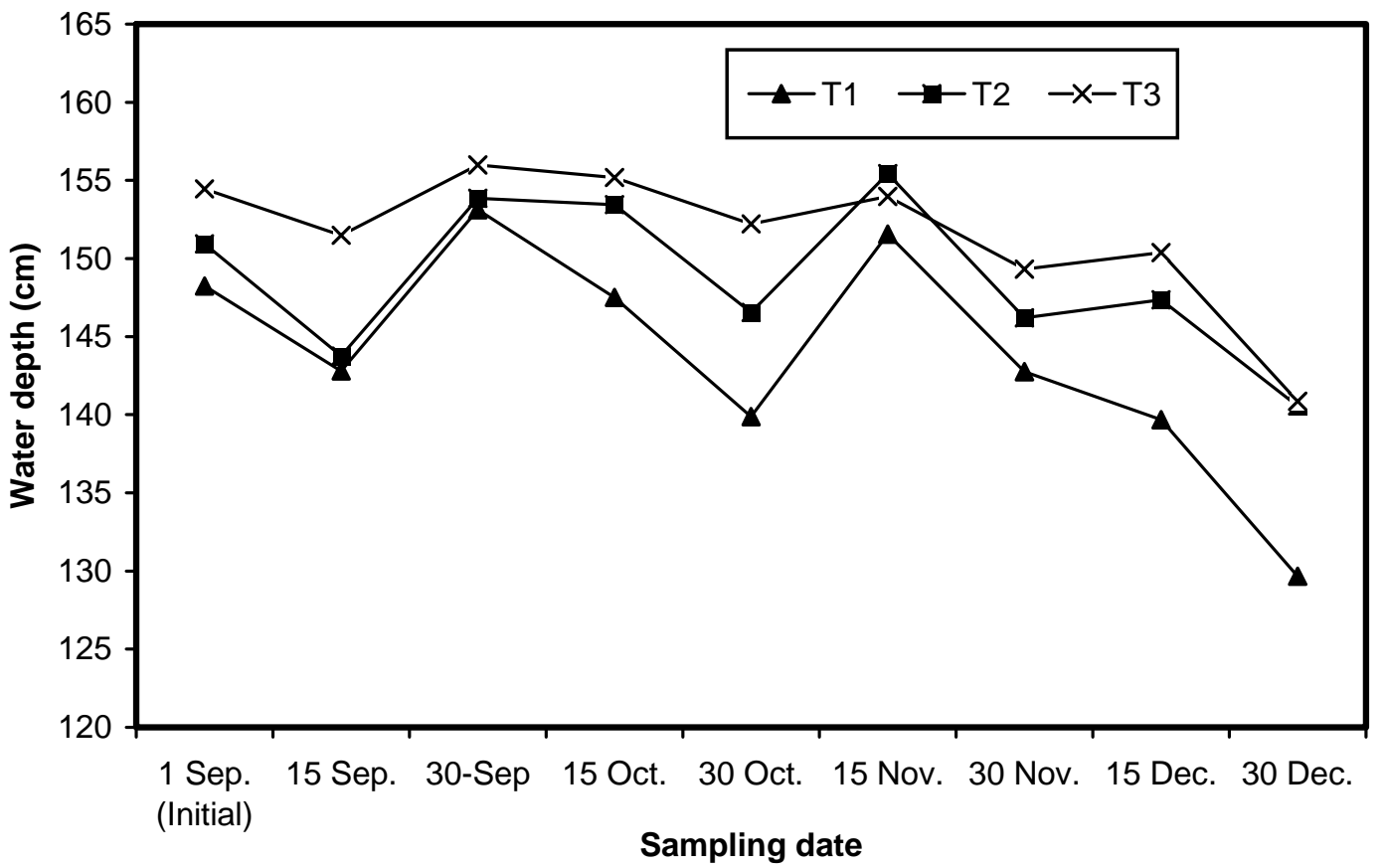

Fig. 1. c Showing the variations of water depth $(\mathrm{cm})$ under three treatments

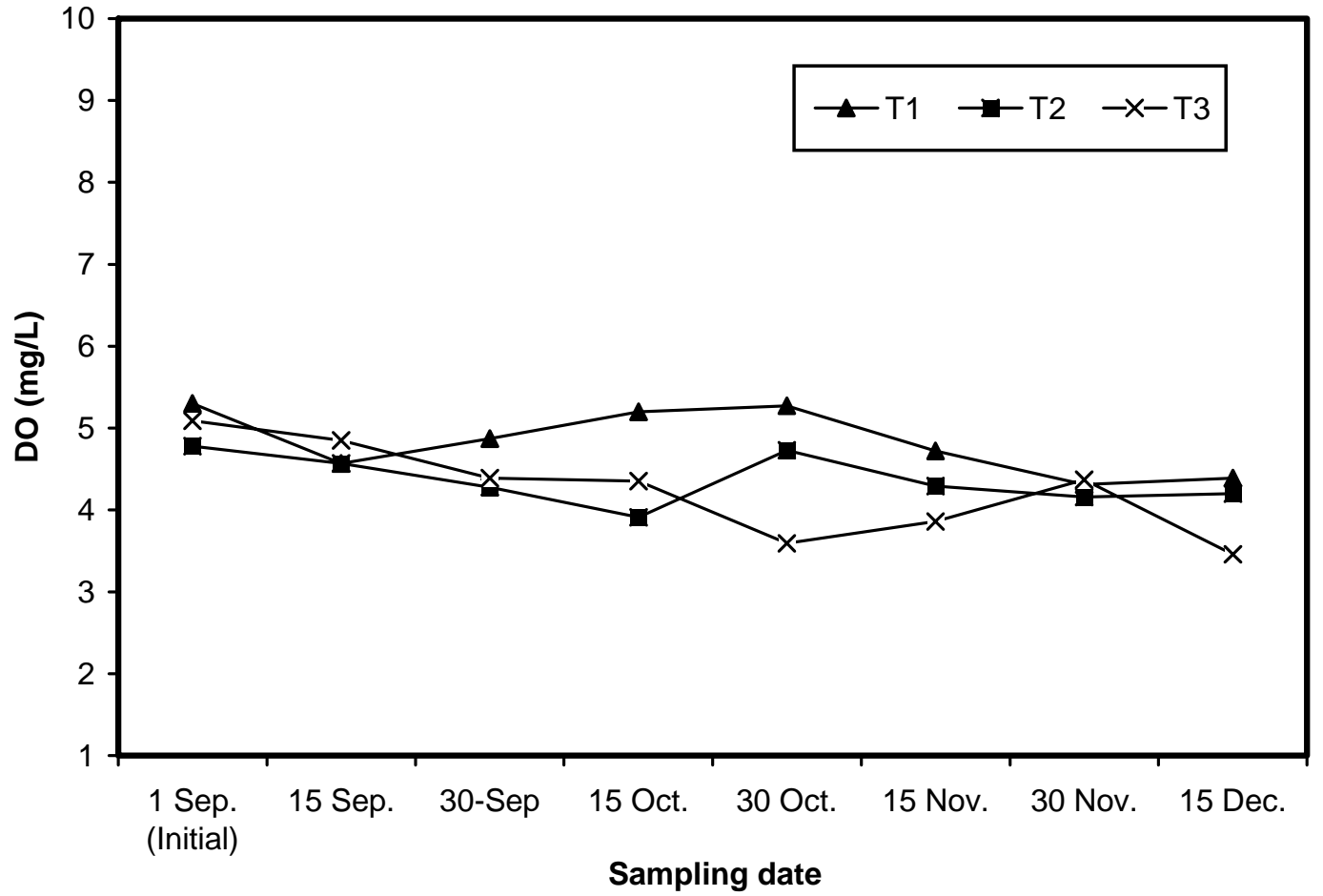

Fig. 1. d Showing the variations of dissolved oxygen $(\mathrm{mg} / \mathrm{L})$ under three treatments 


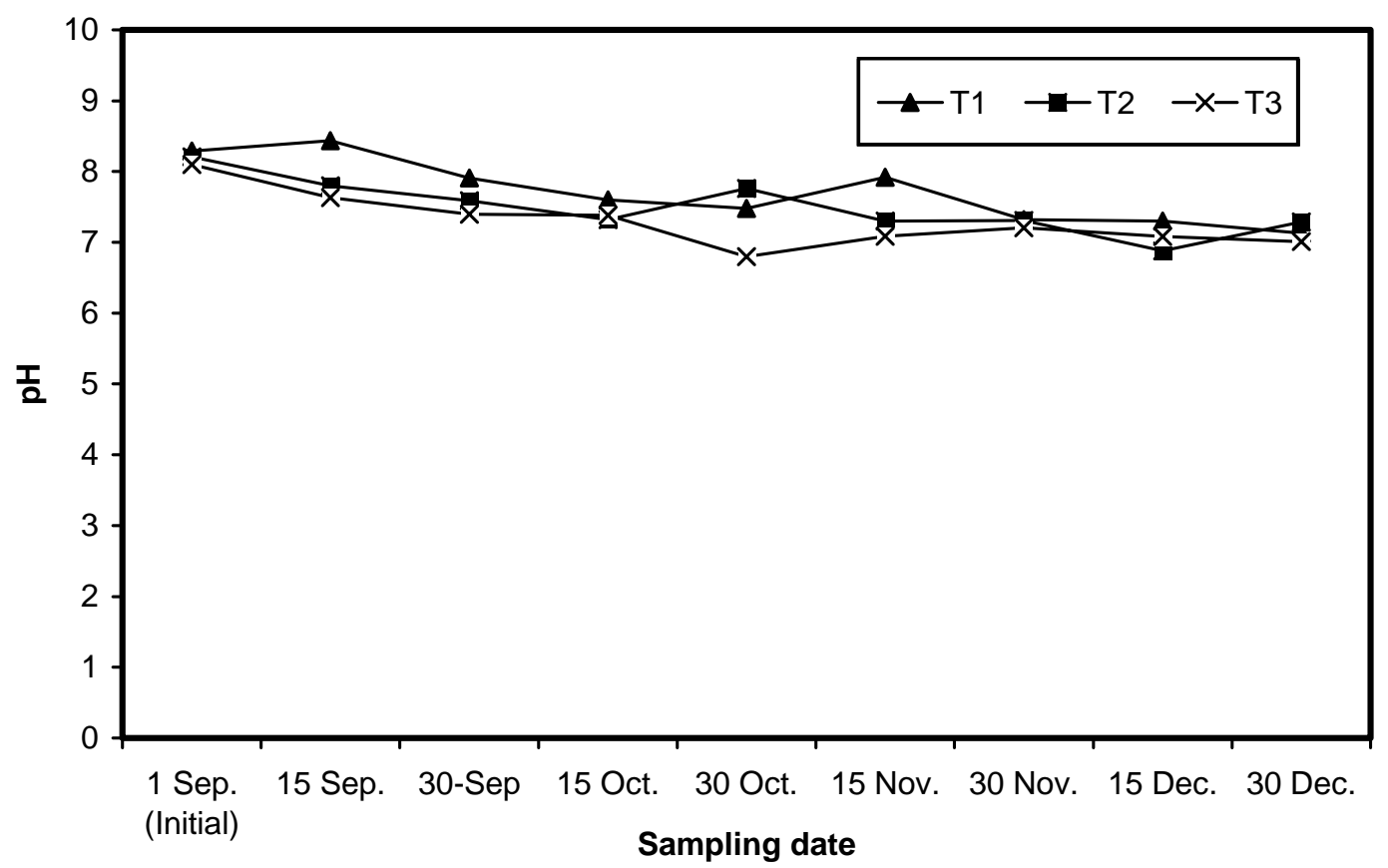

Fig. 1. e Showing the variations of $\mathrm{pH}$ under three treatments

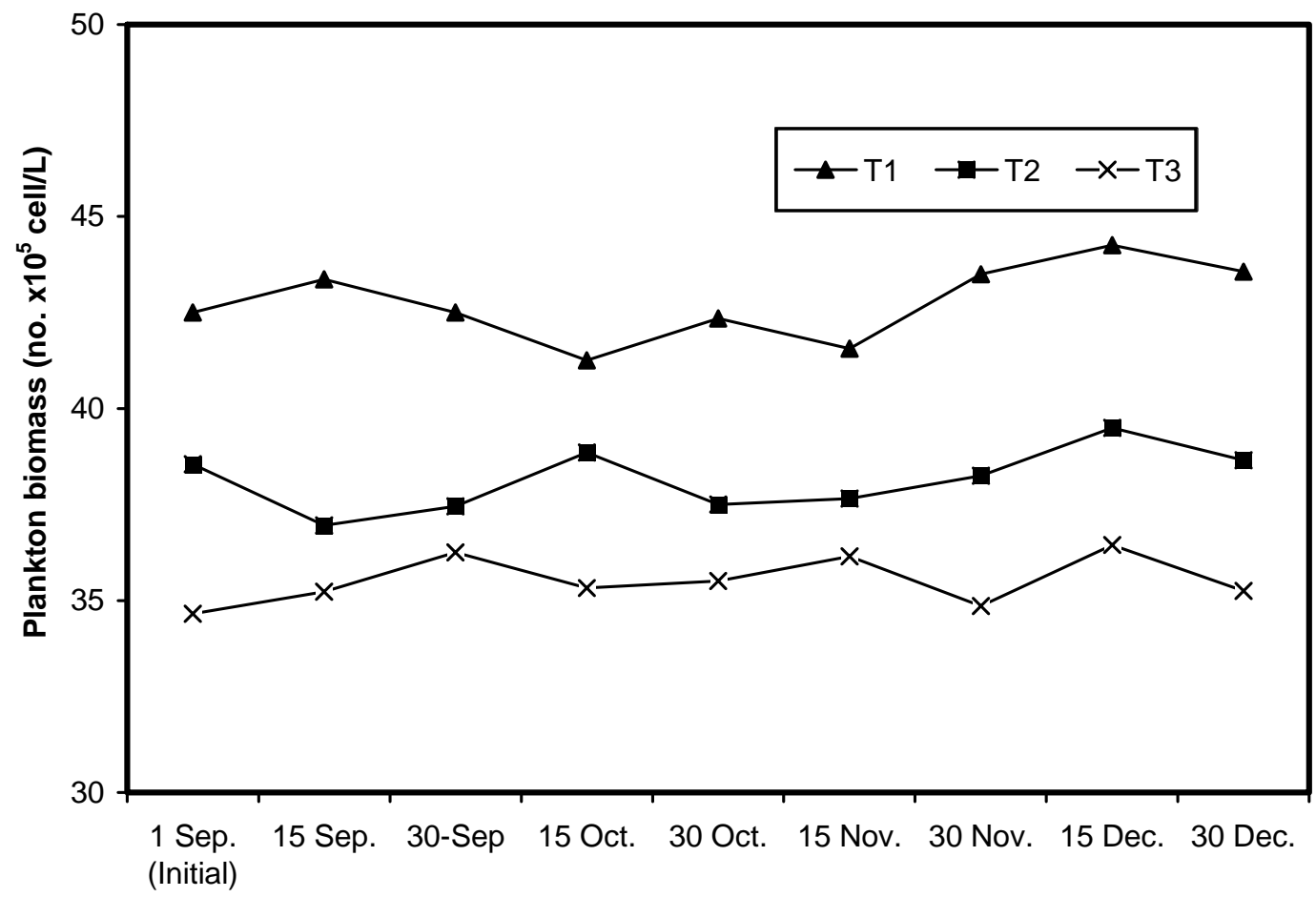

Sampling date

Fig. 1. $f$ Showing the variations of plankton biomass (no. $\times 10^{5}$ cell/L) under three treatments 
Specific growth rate or SGR (\% per day): The specific growth rate of Barbonymus gonionotus in different treatments ranged from $1.47 \pm 0.30$ to $1.73 \pm 0.56$. The lowest specific growth rate $(1.47 \pm 0.30)$ was observed in $T_{3}$ while the significantly $(P<0.01)$ highest specific growth rate $(1.73 \pm 0.56)$ was observed in $T_{1}$ followed by $T_{2}(1.61 \pm 0.35)$.

Average daily gain (g): The average daily gain (g) of Barbonymus gonionotus in different treatments ranged from $1.65 \pm 0.72$ to $1.20 \pm 0.23$. The lowest average daily gain (g) was $1.20 \pm 0.23$ observed in $\mathrm{T}_{3}$ while the significantly $(P<0.01)$ highest average daily gain $(\mathrm{g})$ was $(1.65 \pm 0.72)$ observed in $T_{1}$ followed by $T_{2}(1.54 \pm 0.50)$.

Cumulative weight gain (g): The cumulative weight gain of Barbonymus gonionotus in different treatments ranged from $41.09 \pm 1.66$ to $55.88 \pm 1.47$. The lowest cumulative weight gain $(\mathrm{g})$ was $41.09 \pm$ 1.47 observed in $T_{3}$ while the significantly $(P<0.01)$ highest cumulative weight gain $(\mathrm{g})$ was $55.88 \pm 1.66$ observed in $\mathrm{T}_{1}$ followed by $\mathrm{T}_{2}(48.43 \pm 1.80)$.

Table 2. The mean values ( \pm SD) of growth parameters of Barbonymus gonionotus under three treatments

\begin{tabular}{|c|c|c|c|c|}
\hline \multirow[t]{2}{*}{ Growth parameters } & \multicolumn{3}{|c|}{ Mean $( \pm$ SD) values } & \multirow{2}{*}{ F value } \\
\hline & $T_{1}$ & $T_{2}$ & $T_{3}$ & \\
\hline Weight gain (g) & $48.87 \pm 1.17^{\mathrm{a}}$ & $41.43 \pm 1.80^{b}$ & $34.09 \pm 1.47^{b}$ & 48.393 ** \\
\hline Percent weight gain (\%) & $698.21 \pm 16.67^{\mathrm{a}}$ & $591.93 \pm 25.76^{\mathrm{a}}$ & $487 \pm 21.01^{b}$ & 48.393 ** \\
\hline SGR (\% Per day) & $1.73 \pm 0.56^{\mathrm{a}}$ & $1.61 \pm 0.35^{\mathrm{a}}$ & $1.47 \pm 0.30^{\mathrm{a}}$ & $45.78^{* *}$ \\
\hline ADG (g) & $1.65 \pm 0.72^{\mathrm{a}}$ & $1.54 \pm 0.50^{\mathrm{a}}$ & $1.20 \pm 0.23^{b}$ & $48.393^{* *}$ \\
\hline Cumulative weight gain (g) & $55.88 \pm 1.66^{a}$ & $48.43 \pm 1.80^{a}$ & $41.09 \pm 1.47^{b}$ & 48.393 ** \\
\hline
\end{tabular}

** Significant at $1 \%$ level of significance

Figures in the same row with sane letters are not significantly different $(P>0.01)$

Proximate composition of experimental diet: The proximate composition of fine rice bran used in the experiment has been analyzed and the results are shown in Table 3. Dry matter content was $88.14 \%$, protein content was $9.53 \%$, lipid content was $9.81 \%$, ash content was $13.59 \%$, crude fibre content was $4.76 \%$ and nitrogen free extract (NFE) was $50.45 \%$.

Table 3. Proximate composition of rice bran (\% dry matter basis) used during Barbonymus gonionotus monoculture

\begin{tabular}{|c|c|}
\hline Components & Percentage (\%) \\
\hline Dry matter & 88.14 \\
\hline Protein & 9.53 \\
\hline Lipid & 9.81 \\
\hline Ash & 13.59 \\
\hline Crude fibre $^{1}$ & 4.76 \\
\hline NFE $^{1}$ & 50.45 \\
\hline
\end{tabular}

${ }^{1}$ Nitrogen free extract calculated as 100- \% (moisture + crude protein + ash + crude fibre)

Production of Thai Sharpunti: The fortnightly variation in weight $(\mathrm{g})$ of Thai Sharpunti in three treatments were done. Thai Sharpunti reached an average final weight of $55.88 \pm 1.66,48.43 \pm 1.80$ and $41.09 \pm 1.47$ in $T_{1}, T_{2}$ and $T_{3}$ respectively.

The highest gross and net productions were observed in $T_{2}$ as 1085.71 and $929.46 \mathrm{~kg} / \mathrm{ha} / 120$ days respectively and lowest were observed in $\mathrm{T}_{3}$ as 1019.64 and $846.43 \mathrm{~kg} / \mathrm{ha} / 120$ days (Fig. 2).

Survival rate (\%): The survival rate of Thai Sharpunti were $93.3,89.64$ and $86.87 \%$ in $T_{1}, T_{2}$ and $T_{3}$ respectively. 


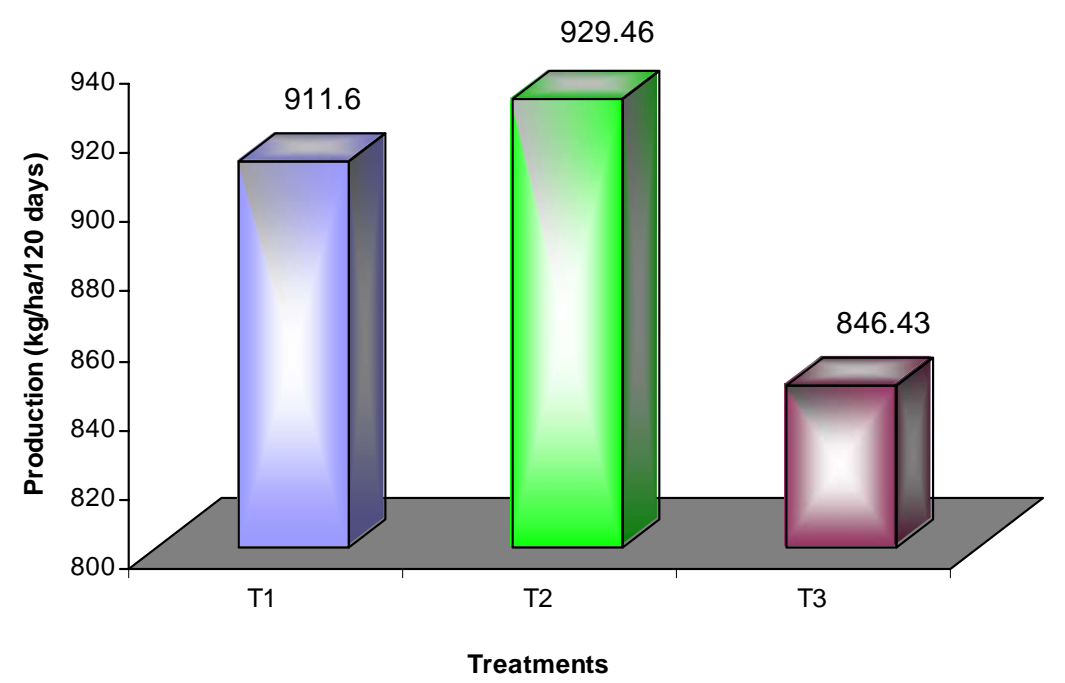

Fig. 2 Showing the net production (kg/ha/120 days) of Thai Sharpunti

\section{Water quality parameters}

Environmental parameters have great influence on the maintenance of a good and healthy aquatic environment and production of sufficient fish food organisms. The water quality parameters like physical, chemical and biological factors play an important role in the water body for fish production. Zhang et al. (1987) observed that the physico-chemical parameters are largely determined by the pond size, shape, depth, fish species, density etc. The physical, chemical and biological factors measured during the experimental period were within the acceptable ranges for fish culture.

Water temperature is one of the most important factors for the growth of aquatic organisms. It influences the other physical, chemical and biological factors of a water body. The increase in temperature within effective range increases the biochemical activity of the micro biota and decomposition of organic matter at the bottom and thereby increases the nutrient status of water body. During the experimental period, water temperature was found to vary from 25.40 to $33.30{ }^{\circ} \mathrm{C}, 25.30$ to $33.10^{\circ} \mathrm{C}$ and 25.20 to $33.20{ }^{\circ} \mathrm{C}$ in $\mathrm{T}_{1}, \mathrm{~T}_{2}$ and $\mathrm{T}_{3}$ respectively. Paul (1998) recorded a temperature range from 26.7 to $33.7^{\circ} \mathrm{C}$ in the ponds of Bangladesh Agricultural University campus. In the present study, the highest water temperature recorded was $34.35{ }^{\circ} \mathrm{C}$ during the month of September and the lowest of $25.20^{\circ} \mathrm{C}$ was recorded in December.

Dissolved oxygen (DO) is the most important chemical factor for all aquatic organisms except anaerobic bacteria. Oxygen regulates the metabolic process of plants and animals and also serves as an indicator of water conditions. In the present study, dissolved oxygen was found to vary from 3.84 to $5.30,3.91$ to 4.78 and 3.46 to $5.09 \mathrm{mg} / \mathrm{l}$ in $\mathrm{T}_{1}, \mathrm{~T}_{2}$ and $\mathrm{T}_{3}$ respectively. The highest and lowest dissolved oxygen content were recorded (5.30 and $3.46 \mathrm{mg} / \mathrm{L})$ in the months of September and December respectively. Hasan (1998) recorded DO to range from 1.1 to $6.87 \mathrm{mg} / \mathrm{l}$, while Wahab et al. (1995) recorded a low DO ranging from 2.0 to $7.2 \mathrm{mg} / \mathrm{l}$ during their experiment from the ponds of BAU campus. The results indicate that the DO concentrations in the water of the ponds were satisfactory and within the productive range.

$\mathrm{pH}$ is a very important factor of water body for the culture of fish. It controls the amount of soluble ions in the water. It is also called the productivity index of a water body. An acidic $\mathrm{pH}$ of water reduces the growth rate, metabolic rate and other physiological activities of fishes (Swingle 1967). He also showed pH values varying even from 6.5 to 9.0 as satisfactory. Lower values of $\mathrm{pH}$ are known to adversely affect plankton production and subsequent growth of fishes. In the present study, the values of $\mathrm{pH}$ were 7.13 to $8.44,6.88$ to 8.21 and 6.80 to 8.10 in $T_{1}, T_{2}$ and $T_{3}$ respectively. The highest and lowest $p H$ values were found to be 8.29 and 6.80 in the month of September and October in $T_{1}$ and $T_{3}$ respectively. Ali et al. (1982) recorded $\mathrm{pH}$ to range from 7.5 to 9.5 in a fresh water pond. Mumtazuddin et al. (1982) found a $\mathrm{pH}$ value of slightly more than 7 in pond water. The present study showed that the $\mathrm{pH}$ values were in neutral or slightly alkaline range in all ponds which indicated good productivity. 
Transparency is an important physical factor which indicates the productivity of a water body. Secchi disc reading between 20 and $30 \mathrm{~cm}$ means the water body to be productive if it is not newly constructed or turbid due to rainfall. Secchi disc reading and productivity are inversely related. In the present study, transparency ranged from 19.89 to $46.90 \mathrm{~cm}$ which was near the findings of Kohinoor et al. (1994) who recorded transparency values to range from 15 to $58 \mathrm{~cm}$. Rahman (1992) concluded that the transparency of productive water bodies should be $40 \mathrm{~cm}$ or less. The highest and lowest transparency of water bodies were 46.90 and $19.89 \mathrm{~cm}$ in the month of September and December in $\mathrm{T}_{3}$ and $\mathrm{T}_{1}$ respectively.

Water depth is also an important parameter in a culture pond because it has direct relation on the productivity. In the present study, depth of water bodies ranged from 129.67 to $156 \mathrm{~cm}$. The highest and lowest water depths were 129.67 and $156 \mathrm{~cm}$ during the month of December and September in $T_{1}$ and $T_{3}$ respectively. The water depth was in productive range according to the area of water bodies.

Plankton biomass in the present study was more or less similar in $\mathrm{T}_{2}$ and $\mathrm{T}_{3}$ but comparatively higher in $T_{1}$. It may be due to the lower stocking density of Sharpunti in treatment 1 . The highest and lowest plankton number were recorded as $44.25 \times 10^{5} / /$ and $34.65 \times 10^{5} / /$ during the months of December and September in $T_{1}$ and $T_{3}$ respectively.

\section{Growth and production of Thai Sharpunti}

In the present study, Thai Sharpunti reached an average final weight of $55.88 \pm 1.66,48.43 \pm 1.80$ and $41.09 \pm 1.47 \mathrm{~g}$ in $\mathrm{T}_{1}, \mathrm{~T}_{2}$ and $\mathrm{T}_{3}$ respectively. The total net production recorded in $\mathrm{T}_{1}, \mathrm{~T}_{2}$ and $\mathrm{T}_{3}$ were $911.60,929.46$ and $846.43 \mathrm{~kg} / \mathrm{ha} / 120$ days respectively.

In the present study, the SGR (\% per day) of Sharpunti were $1.73 \pm 0.56,1.61 \pm 0.35$ and $1.47 \pm 0.30$ in $T_{1}, T_{2}$ and $T_{3}$ respectively.

The average daily gain (ADG) of Thai Sharpunti were $1.65 \pm 0.72,1.54 \pm 0.50$ and $1.20 \pm 0.23 \mathrm{~g}$ in $\mathrm{T}_{1}, \mathrm{~T}_{2}$ and $T_{3}$ respectively. Islam (1996) reported that ADG of rohu, catla and mrigal were $0.48,0.60$ and 0.62 which more or less agreed with the results of the present study. In carp culture there is a positive correlation between pond size and growth (Ameen et al. 1986) which might be true for the present study.

\section{Weight gain}

Weight gain (g) of Sharpunti was $48.87 \pm 1.17 \mathrm{~g}$ in $\mathrm{T}_{1}, 41.43 \pm 1.80 \mathrm{~g}$ in $\mathrm{T}_{2}$ and $34.09 \pm 1.47 \mathrm{~g}$ in $\mathrm{T}_{3}$ respectively. Weight gain of Sharpunti was the highest in $T_{1}$.

\section{Survival rate}

During the period of study, the survival rates of Barbonymus gonionotus were more or less similar in all treatments (93.30\% in $\mathrm{T}_{1}, 89.64 \%$ in $\mathrm{T}_{2}$ and $86.87 \%$ in $\mathrm{T}_{3}$ ) and there is no significant difference among them. Kohinoor et al. (1993) also reported similar survival rate (86 to 94\%) during monoculture of Barbonymus gonionotus.

\section{Total production}

The net production of Sharpunti were $911.60,929.46$ and $846.43 \mathrm{~kg} / \mathrm{ha} / 120$ days in $T_{1}, T_{2}$ and $T_{3}$ respectively. The overall production of $T_{2}$ was significantly higher than those of $T_{1}$ and $T_{3}$.

The result of the present study showed that $B$. gonionotus is well suited to culture at stocking density of $80 /$ decimal. The species can reach an average size of over $55.88 \mathrm{~g}$ within a culture period of 4 months which is well accepted as market size of Thai Sharpunti in Bangladesh. 


\section{References}

Ali, S., Ataur Rahman, A.K., Patwary, A.R. and R. Islam, K.H. 1982. Studies on the diurnal variations in physico-chemical factors and zooplankton in freshwater pond. Bangladesh J. Fish., 2-5 (1-2): 15-23.

Ameen, M., Rahman, P.M. and Ahmed, M.U. 1986. Baseline survey on agricultural resources in Feni, Lakshmipur, Noakhali district. Fish., Com./NRDP/DANID, Dhaka, 85 pp.

AOAC (Association of Official Analytical Chemicsts), 1980. Official methods of analysis. Association of Official Analytical Chemists, W. Howritz (Editor), $13^{\text {th }}$ edition. Washington, D. C. p. 30-32.

Backiel, T.E.D. and Le Cren. 1978. Some density relationship for fish population parameters. Biology of Freshwater Fish production. S. D. Gerking, Black well Scientific publications, Oxford, 279-302 pp.

Brett, J.R. 1974. Marine fish Aquaculture in Canada. P 55-84. On H. R. Mac Crimmon, J. E. Steward and J. R. Brett (Editors) Aquaculture in Canada. The practice and the promise. Department of the Environmental Fisheries and Marine Service, Ottowa, Canada.

Gupta, M.V. 1991. Low-input technologies for rural aquaculture development in Bangladesh. Paper presented at BOSTID-ICLARM Aquaculture Workshop for PSTC/CRD Scientists 6-10 August 1991. Manila. Philippines, pp. 53-57.

Gupta, M.V. and Rab, M.A. 1994. Adoption and economies of sliver Barb (Puntius gonionotus) culture in seasonal water in Bangladesh. ICLARM Technical Report 41.Manila, Philippines, pp. 71-75.

Hasan, M.A. 1998. Development of carp polyculture techniques with small indigenous fish species mola (Amblypharyngodon mola), chela (Chela ichelacachius) and punti (Puntius sophore). M. S. Thesis. Dept. of Fisheries Management, Bangladesh Agricultural University, Mymensingh. 71 pp.

Islam, A. 1996. A report on aquatic culture in Bangladesh. Fish Inf. B. Bangladesh Fish. Res. Sy. System, 1 (2): 1-28.

Johnson, W. E. 1965. On mechanism of self regulation of population abundance in Oncorhynchus nerca Mitt. Int. Verin. theor. Angew. Limnol., 13: 66-87.

Karim, K.A.T.A., Dewan, S. and Hossain, M.G. 1988. Length weight relationship and condition factor of Puntius gonionotus (Bleeker). Bangladesh J. Aquaculture. 10: 49-54.

Kohinoor, A.H.M., Akhteruzzaman, M. and Shah, M.S. 1993. Production of Puntius gonionotus (Bleeker) in ponds. Bangladesh J. Zool., 21 (2): 77-83.

Kohinoor, A.H.M., Asaduzzaman, M. and Jahan, D.A. 1994a. Culture of Rajpunti, Puntius gonionotus in rice field. Progr. Agric., 5 (2): 267-272.

Kohinoor, A.H.M., Hossain, M.G., Mazid, M.A., Jahan, D.A. and Gupta, M.V. 1994. Comparative production performance of Rajpunti. Puntius gonionotus and local sharpunti. Puntius sarana in a semi intensive culture system. Progr. Agric., 5 (1): 49-53.

Mumtazuddin, M., Rahman, M.S. and Mostafa, G. 1982. Limnological studies of four selected ponds at the Aquaculture Experiment Station. Mymensingh. Bangladesh J. Fish., 2-5: 83-162.

Paul, S. 1998. Comparison between carp polyculture system with silver carp (Hypohthalmichthys molitrix) and with small indigenous fish mola (Amblypharyngodon mola). M. S. thesis. Dept. of Fisheries Management BAU, Mymensingh. pp. 24-29.

Rahman, M.S. 1992. Water quality management in Aquaculture. BRAC PROKASHANA 66, Mohakhali, Dhaka - 1212. Bangladesh. $75 \mathrm{pp}$.

Swingle, H.S. 1967. Relationships of pH of pond water to their suitability for fish culture. Proc. $9^{\text {th }}$ Pacific Sci. Congr., 10: $72-75$.

Wahab, M.A., Rahmatullah, S.M., Beveridge, M.C.M., Baird, D.J. and Tollervey, A.G. 1995. Impact of shar punti (Puntius gonionotus) in the polyculture of native major carps and mitigative measures using duckweed (Lemna sp.). A paper presented in the "Fourth Asian Fisheries Forum" held in Beijing, China.

Weatherly, A.H. 1976. Factors affecting maximization of fish growth. J. Fish Res. Bol. Can., 22: 1046-1048.

Zhang, F.I., Zhe and Zhou, X.Y. 1987. Studies on the ecological effects of varying the size of fish ponds loaded with manures and feeds. Aquaculture., 60: 107-116. 